\title{
Permanent Neonatal Diabetes Mellitus: Same Mutation, Different Glycemic Control with Sulfonylurea Therapy on Long-Term Follow-up
}

\author{
Banu Küçükemre Aydın, Rüveyde Bundak, Firdevs Baş, Hülya Maraş, Nurçin Saka, \\ Hülya Günöz, Feyza Darendeliler \\ Istanbul University Faculty of Medicine, Department of Pediatric Endocrinology, Istanbul, Turkey
}

\begin{abstract}
Permanent neonatal diabetes mellitus (PNDM) is a rare condition presenting before six months of age. Mutations in the genes encoding the ATP-sensitive potassium $\left(\mathrm{K}_{\text {ATP }}\right)$ channel are the most common causes. Sulfonylurea (SU) therapy leads to dramatic improvement in diabetes control and quality of life in most patients who carry these mutations. Here, we report the long-term follow-up results of two siblings with PNDM who were treated with insulin until $A B C C 8$ gene mutation was identified, and were successfully transferred to oral SU therapy. After 3.5 years of follow-up on SU, one patient had a very good response, while the other one had a poor response. Bad compliance to diet was thought to be the most probable reason for poor glycemic control in this patient. In conclusion, molecular genetic diagnosis in all patients with PNDM is recommended. Compliance to treatment should be an important aspect of the follow-up of these patients.
\end{abstract}

Key words: Diabetes mellitus, ABCC8, SUR1, sulfonylurea

Conflict of interest: None declared

Received: 29.10.2011

Accepted: 02.01.2012

\section{Introduction}

Permanent neonatal diabetes mellitus (PNDM) is a form of insulin-requiring diabetes presenting before six months of age and is likely to be non-autoimmune in nature. It is a rare condition occurring in only 1.43-1.96/ 100000 infants (1). Affected infants frequently present with symptomatic hyperglycemia and sometimes with ketoacidosis (2). As a result of lower foetal insulin production, birth weight is low in most infants with PNDM (1). It is now accepted that most neonates and infants presenting with diabetes within the first 6 months of life have a monogenic form of disease although the responsible gene remains unknown in up to $40 \%$ of patients (3). The most common causes of PNDM are mutations in the genes (KCNJ11 and ABCC8) encoding the two protein subunits [Kir6.2 and sulfonylurea receptor 1 (SUR1), respectively] of the ATP-sensitive potassium (K $K_{\text {ATP }}$ ) channel and in the gene encoding insulin itself $(3,4,5,6,7,8)$. $K_{\text {ATP }}$ channel is a critical regulator of beta-cell insulin secretion. Insulin secretion is initiated by closure of the channels and inhibited by their opening. The K $\mathrm{K}_{\text {ATP }}$ channel is an octameric complex consisting of four Kir6.2 and four SUR1 subunits. In case of activating mutations in Kir6.2 or SUR1, the K KTP channel remains open leading to impaired insulin secretion and neonatal diabetes. In contrast, loss-of-function mutations in SUR1 or Kir6.2 lead to congenital hyperinsulinemia by the same mechanism (9). Identification of the underlying genetic cause has led to improved treatment for patients with a mutation in KCNJ11 or $A B C C 8$. 
Küçükemre $B$ et al.

Neonatal Diabetes Mellitus

These patients usually respond to high-dose sulfonylurea (SU) therapy, with significantly improved glycemic control $(10,11)$.

In this paper, we report the long-term follow-up of two siblings with PNDM who were treated with insulin until $A B C C 8$ gene mutation was detected, and who were transferred from insulin to SU.

\section{Case Report}

Patient 1: The first patient was a male infant, diagnosed with diabetes at the age of 5 months in another hospital. According to this hospital's report, his physical examination was normal when he first presented with focal seizures. His routine laboratory analyses revealed normal serum chemistry, except for high blood glucose levels (528 mg/dL), and normal values for blood gases. Insulin therapy was started and the patient stayed for one month in that hospital. One month later, the infant was referred to our hospital for glycemic regulation; stable metabolic control was achieved with $0.5 \mathrm{U} / \mathrm{kg} /$ day NPH insulin. The patient's initial $\mathrm{HbA} 1 \mathrm{c}$ and insulin levels were $12.5 \%$ and $5.8 \mathrm{uU} / \mathrm{mL}$, respectively; exocrine pancreas functions were normal. Examination of the stool for occult blood, fat, meat fibers and $\mathrm{pH}$ revealed no pathology. His cranial imaging and EEG were unremarkable. The seizures did not recur, and his neuromotor development was normal during the follow-up.

Patient 2: The second patient was a 2.5-month-old male infant whose blood glucose was checked because of a history of PNDM in his older brother (Patient 1, presented above). The infant was admitted to our hospital with a blood glucose level of $570 \mathrm{mg} / \mathrm{dL}$. The parents stated that they had not observed any symptoms and reported a weight gain of $2 \mathrm{~kg}$ in the first 2 months of life. Physical examination, venous blood gas and electrolyte levels were all normal. $\mathrm{HbA1c}$ level was $8.9 \%$. The patient was discharged with $0.4 \mathrm{U} / \mathrm{kg} /$ day insulin therapy.

Both patients were followed and received insulin treatment until they were 15 2/12 and 109/12 years old, at which time their diagnosis of diabetes was established to be due to an $A B C C 8$ gene mutation, identified by sequencing analysis in Exeter, U.K. Genetic studies revealed a novel homozygous missense mutation, p.E382K, in exon 7 of $A B C C 8$ gene (12). This $G>A$ mutation at nucleotide 1144 (c. $1144 \mathrm{G}>\mathrm{A}$ ) results in the substitution of lysine (basic charged polar amino acid) for glutamic acid (acidic charged polar amino acid) at codon 382 (p.Glu382Lys). The glutamic acid residue at codon 382 is conserved across species. This result was consistent with the diagnosis of recessively inherited neonatal diabetes due to the mutation in the SUR1 subunit of the $\mathrm{K}_{\text {ATP }}$ channel. The parents were first-degree cousins and both of them were heterozygous for the E382K missense mutation (Figure 1).

The patients were hospitalized in our clinic for a change of their therapy from insulin to SU. Prior to SU treatment, total daily insulin dose was $0.9 \mathrm{U} / \mathrm{kg} /$ day in the older patient and 1.0 $\mathrm{U} / \mathrm{kg} /$ day in his younger brother. Their $\mathrm{HbA} 1 \mathrm{c}$ levels were $8.1 \%$ and $8 \%$, respectively. Oral glibenclamide was started in a dose of $0.1 \mathrm{mg} / \mathrm{kg} /$ day and gradually increased up to a final dose of 0.8 $\mathrm{mg} / \mathrm{kg} /$ day twice daily in one week. Insulin requirements were decreased by $50 \%$ within one week. At the end of the week, Cpeptide levels increased from 0.07 to $2.2 \mathrm{ng} / \mathrm{mL}$ and from 0.17 to $2 \mathrm{ng} / \mathrm{mL}$, respectively. Insulin therapy was stopped at the end of two months. Blood glucose levels remained within normal ranges on glibenclamide therapy. $\mathrm{HbA} 1 \mathrm{c}$ levels decreased to $6.3 \%$ and $6.4 \%$ (normal ranges $4.5-6.5 \%$ ) in patient 1 and 2, respectively (Table 1).

Currently, the patients have been on SU therapy for 3.5 years, and no side effects were reported. The older sibling has a good glycemic control (HbA1c 6.7\%) with a lower dose of SU $(0.4 \mathrm{mg} / \mathrm{kg} / \mathrm{day})$, but the younger has poor glycemic control ( $\mathrm{HbA} 1 \mathrm{c} 10.1 \%$ three months prior to the last visit and $7.9 \%$ at the last visit) even with a higher dose of SU (0.6 mg/ $/ \mathrm{kg} / \mathrm{day})$ (13). Both patients have low body mass indices (BMI) $16.7 \mathrm{~kg} / \mathrm{m}^{2}[-2.86$ standard deviation score (SDS)] and $17.5 \mathrm{~kg} / \mathrm{m}^{2}$ (-1.45 SDS), respectively. With glucagon stimulation, C-peptide level was higher in the younger sibling (1.64 vs. $2.24 \mathrm{ng} / \mathrm{mL}$ ) (Table 1). The younger sibling claimed he was well compliant with the SU treatment, but he admitted not being completely compliant with his diet. The parents confirmed that their son was regularly taking the SU tablets. Before increasing the SU dose, we decided to follow the patient's compliance to the current therapy. Over the following 3 months, the patient showed an increasingly good compliance to the diet and his blood glucose control significantly improved without any increase in SU daily dose and the $\mathrm{HbA} 1 \mathrm{c}$ level decreased below $8 \%$.

\section{Discussion}

The discovery of a genetic background in PNDM had a large impact on the management of the affected subjects. Most of the patients with the molecular diagnosis of PNDM resulting from $K C N J 11$ and $A B C C 8$ gene mutations could be transferred from insulin to SU treatment. SU are drugs of choice to treat type 2 diabetes mellitus, they close $\mathrm{K}_{\text {ATP }}$

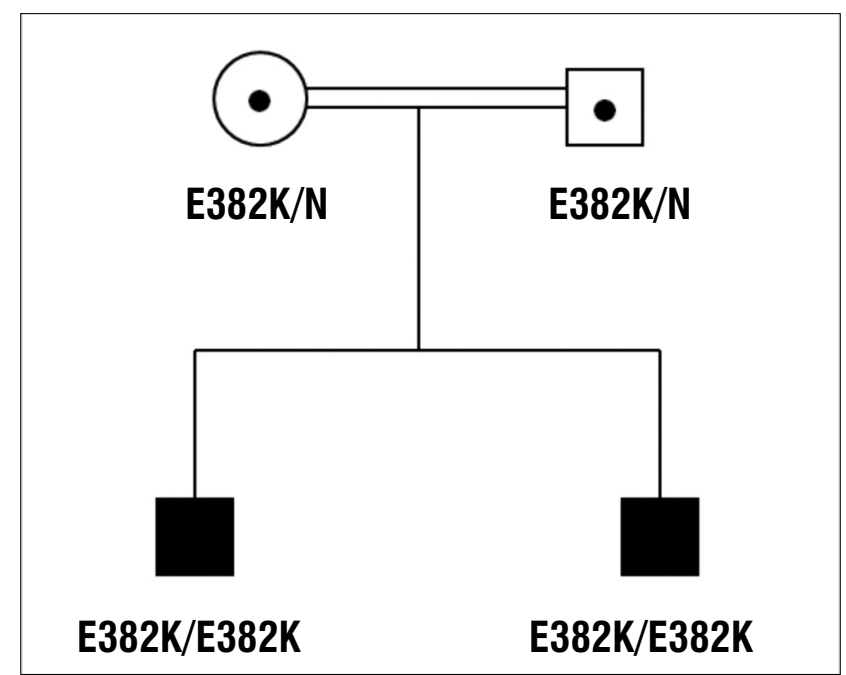

Figure 1. Pedigree of the family 
channels by an ATP-independent route, thereby causing insulin secretion. They can close these channels even when mutations are present, so SU are a better treatment option in PNDM caused by mutations in these channels $(5,6,10,11)$.

Due to the mutated $K_{\text {ATP }}$ channels in neural tissue, some PNDM patients exhibit developmental delay, epilepsy and neonatal diabetes (DEND) syndrome. Especially in patients with a milder form, referred to as the intermediate DEND syndrome, even neurological symptoms can improve with SU therapy (14). Since our patients did not have developmental delay, epilepsy or muscle weakness, a diagnosis of DEND syndrome was ruled out.

In PNDM caused by mutations in $\mathrm{K}_{\text {ATP }}$ channels, glycemic control with $\mathrm{SU}$ is often better than that accomplished by insulin, as also observed in our patients at the beginning of their therapy. After 3.5 years of follow-up, although both siblings carried the same $A B C C 8$ gene mutation, they showed a different glycemic control on $\mathrm{SU}$.

Unsuccessful switching from insulin to SU has been reported in $10 \%$ of children and adults who are $\mathrm{K}_{\text {ATP }}$ channel mutation carriers (15). The failure of SU in some of these patients can be, at least partially, explained by the severity of their alterations. Nevertheless, additional factors, such as the age of the patient, can influence this response (1). Sometimes, even identical mutations within the same families can produce a variable clinical picture $(15,16,17)$. However, no case of secondary failure of SU in PNDM has been reported so far (1). About $50 \%$ of type 2 diabetic patients treated with SU experience a severe deterioration of metabolic control within 6 years of therapy initiation. This phenomenon may derive from a loss of insulin secretory capascity due to the hyperexcitability of pancreatic beta cells chronically exposed to this drug (18). Lafusco et al (18) investigated 11 patients who were carriers of $K_{\text {ATP }}$ channel mutation and had been on SU therapy for more than 57 months and showed that chronic SU therapy retains its efficacy for a long period of time in patients with PNDM, contrary to findings reported in type 2 diabetes.

Compliance is one of the most important practical aspects in long-term treatment, especially in adolescents (19). In our

Table 1. Clinical characteristics of patients according to success of SU treatment

\begin{tabular}{|c|c|c|}
\hline & Patient 1 & Patient 2 \\
\hline Age at diagnosis (months) & 5 & 2.5 \\
\hline Birth weight $(\mathrm{kg})$ & 3.0 & 2.7 \\
\hline Ketoacidosis at onset & - & - \\
\hline Molecular study & $\mathrm{E} 382 \mathrm{~K}$ in $\mathrm{ABCC} 8$ & $\mathrm{E} 382 \mathrm{~K}$ in $\mathrm{ABCC} 8$ \\
\hline Age at start of SU treatment (years) & 15.2 & 10.8 \\
\hline Insulin dose before SU treatment (U/kg/day) & 0.9 & 1.0 \\
\hline C-peptide level before SU treatment $(\mathrm{ng} / \mathrm{mL})$ & 0.07 & 0.17 \\
\hline C-peptide level after SU treatment $(\mathrm{ng} / \mathrm{mL})$ & 2.20 & 2.0 \\
\hline HbA1c level before SU treatment $(\%)$ & 8.1 & 8.0 \\
\hline HbA1c level after SU treatment (\%) & 6.3 & 6.4 \\
\hline SU dose required to cease insulin treatment ( $\mathrm{mg} / \mathrm{kg} / \mathrm{day})$ & 0.8 & 0.8 \\
\hline Duration of SU treatment (months) & 42 & 42 \\
\hline Age at last medical visit (years) & 18.7 & 14.3 \\
\hline BMI (SDS) at last medical visit $\left(\mathrm{kg} / \mathrm{m}^{2}\right)$ & $16.7(-2.86)$ & $17.5(-1.45)$ \\
\hline Stimulated C-peptide level at last medical visit ( $\mathrm{ng} / \mathrm{mL}$ ) & 1.64 & 2.24 \\
\hline $\mathrm{HbA} 1 \mathrm{c}$ level at last medical visit (\%) & 6.7 & 7.9 \\
\hline SU dose at last medical visit (mg/kg/day) & 0.4 & 0.6 \\
\hline Medical problems observed during SU treatment & None & Poor glycemic control \\
\hline
\end{tabular}


patients, the poor glycemic control of the younger, adolescent sibling was not due to SU secondary failure. With good compliance to his diet and medication, his blood glucose control significantly improved without any increase in SU dose. Although the patient and his family reported good compliance with SU treatment, it could be argued that the $\mathrm{HbA} 1 \mathrm{c}$ increase might be due to the skipping of SU tablets rather than just dietary noncompliance. The low BMl of this patient also supports this argument.

In conclusion, molecular genetic diagnosis is recommended in all patients with PNDM since the identification of Kir6.2 or SUR1 mutations allows a successful change to SU therapy that leads to dramatic improvement in diabetes control and quality of life. However, these patients should be followed closely for compliance to treatment, especially when they are adolescents.

\section{Acknowledgments}

The authors are grateful to Andrew Hattersley and Sian Ellard (Peninsula Medical School, Exeter, United Kingdom) for performing the genetic testing of the patients.

\section{References}

1. Rubio-Cabezas O, Klupa T, Malecki MT, CEED3 Consortium Permanent neonatal diabetes mellitus the importance of diabetes differential diagnosis in neonates and infants. Eur $\mathrm{J}$ Clin Invest 2011:41:323-333.

2. Abaci A, Razi $\mathrm{CH}$, Ozdemir O, Hizli S, Kislal F, Agras PI, Kabakus N. Neonatal diabetes mellitus accompanied by diabetic ketoacidosis and mimicking neonatal sepsis: A case report. J Clin Res Pediatr Endocrinol 2010:2:131-133.

3. Edghill EL, Flanagan SE, Patch AM, Boustred $C$, Parrish $A$, Shields B, Shepherd MH, Hussain K, Kapoor RR, Malecki M, MacDonald MJ, Støy J, Steiner DF, Philipson LH, Bell Gl; Neonatal Diabetes International Collaborative Group, Hattersley AT, Ellard S. Insulin mutation screening in 1044 patients with diabetes: mutations in the INS gene are a common cause of neonatal diabetes but a rare cause of diabetes diagnosed in childhood or adulthood. Diabetes 2008; 57:1034-1042.

4. Gloyn AL, Pearson ER, Antcliff JF, Proks P, Bruining GJ, Slingerland AS, Howard N, Srinivasan S, Silva JM, Molnes J, Edghill EL, Frayling TM, Temple IK, Mackay D, Shield JP, Sumnik Z, van Rhijn A, Wales JK, Clark P, Gorman S, Aisenberg J, Ellard S, Njolstad PR, Ashcroft FM, Hattersley AT. Activating mutations in the gene encoding the ATP-sensitive potassium-channel subunit Kir6.2 and permanent neonatal diabetes. N Engl J Med 2004; 350:1838-1849.

5. Proks $P$, Arnold AL, Bruining J, Girard C, Flanagan SE, Larkin B, Colclough K, Hattersley AT, Ashcroft FM, Ellard S. A heterozygous activating mutation in the sulphonylurea receptor (SUR1) (ABCC8) causes neonatal diabetes. Hum Mol Genet 2006; 15:1793-1800.

6. Babenko AP, Polak M, Cave H, Busiah K, Czernichow P Scharfmann R, Bryan J, Aguilar-Bryan L, Vaxillaire M, Froguel $P$. Activating mutations in the ABCC 8 gene in neonatal diabetes mellitus. N Engl J Med 2006;355:456-466.
7. Støy J, Edghill EL, Flanagan SE, Ye H, Paz VP, Pluzhnikov A, Below JE, Hayes MG, Cox NJ, Lipkind GM, Lipton RB, Greeley SA, Patch AM, Ellard S, Steiner DF, Hattersley AT, Philipson LH, Bell Gl; Neonatal Diabetes International Collaborative Group. Insulin gene mutations as a cause of permanent neonatal diabetes. Proc Natl Acad Sci USA 2007:104:15040-15044.

8. Polak M, Cave H. Neonatal diabetes mellitus: a disease linked to multiple mechanisms. Orphanet J Rare Dis 2007;2:12.

9. Darendeliler F, Fournet JC, Bas F, Junien C, Gross MS, Bundak R, Saka N, Gunoz H. ABCC8 (SUR1) and KCNJ11 (KIR6.2) mutations persistent hyperinsulinemic hypoglycemia of infancy and evaluation of different therapeutic measures. J Pediatr Endocrinol Metab 2002;15:993-1000.

10. Pearson ER, Flechtner I, Niølstad PR, Malecki MT, Flanagan SE, Larkin B, Ashcroft FM, Klimes I, Codner E, lotova V, Slingerland AS, Shield J, Robert JJ, Holst JJ, Clark PM, Ellard S, Søvik O, Polak M, Hattersley AT; Neonatal Diabetes International Collaborative Group. Switching from insulin to oral sulfonylureas in patients with diabetes due to Kir6.2 mutations. N Engl J Med 2006;355:467-477.

11. Rafiq M, Flanagan SE, Patch AM, Shields BM, Ellard S, Hattersley AT; Neonatal Diabetes International Collaborative Group. Effective treatment with oral sulfonylureas in patients with diabetes due to sulfonylurea receptor 1 (SUR1) mutations. Diabetes Care 2008;31:204-209.

12. Ellard S, Flanagan SE, Girard CA Patch AM, Harries LW, Parrish A, Edghill EL, Mackay DJ, Proks P, Shimomura K, Haberland H, Carson DJ, Shield JP. Hattersley AT, Ashcroft F'M. Permanent Neonatal Diabetes Caused by Dominant, Recessive, or Compound Heterozygous SUR1 Mutations with Opposite Functional Effects. Am J Hum Genet 2007:81:375-382.

13. The Global IDF/ISPAD Guideline For Diabetes in Childhood And Adolescence. International Diabetes Federation 2011; ISBN 2-930229-72-1.

14. Zwaveling-Soonawala N, Hagebeuk EE, Slingerland AS, RisStalpers C, Vulsma T, van Trotsenburg AS. Successful transfer to sulfonylurea therapy in an infant with developmental delay, epilepsy and neonatal diabetes (DEND) syndrome and a novel ABCC8 gene mutation. Diabetologia 2011;54:469-471

15. Klupa T, Kowalska I, Wyka K, Skupien J, Patch AM, Flanagan SE, Noczynska A, Arciszewska M, Ellard S, Hattersley AT, Sieradzki J. Mlynarski W, Malecki MT. Mutations in the ABCC8 (SUR1 subunit of the $K_{\text {ATP }}$ channel) gene are associated with a variable clinical phenotype. Clin Endocrinol (Oxf) 2009;71:358-362.

16. Russo C, Salina A, Aloi C, lafusco D, Lorini R, d'Annunzio G. Mother and daughter carrying the same KCNJ11 mutation but with a different response to switching from insulin to sulfonylurea. Diabetes Res Clin Pract 2011;94:50-52.

17. Landau Z, Wainstein J, Hanukoglu A, Tuval M, Lavie J, Glaser B. Sulfonylurea-responsive diabetes in childhood. J Pediatr 2007:150:553-555.

18. Lafusco D, Bizzarri C, Cadario F, Pesavento R, Tonini G, Tumini $S$, Cauvin V, Colombo C, Bonfanti R, Barbetti F. No beta cell desensitisation after a median of 68 months on glibenclamide therapy in patients with KCNJ11-associated permanent neonatal diabetes. Diabetologia 2011:54:2736-2738.

19. Jónasson G, Carlsen KH, Sødal A, Jonasson C, Mowinckel P. Patient compliance in a clinical trial with inhaled budesonide in children with mild asthma. Eur Respir J 1999;14:150-154. 